\title{
Correction to: Comparing the horizontal and vertical approaches used to identify foraging areas of two diving marine predators
}

\author{
Yann Planque $^{1}\left[\right.$ - Mathilde Huon ${ }^{1} \cdot$ Florence Caurant $^{1} \cdot$ David Pinaud $^{2} \cdot$ Cécile Vincent $^{1}$
}

Published online: 5 August 2020

c) Springer-Verlag GmbH Germany, part of Springer Nature 2020

Correction to: Marine Biology (2020) 167:25

https://doi.org/10.1007/s00227-019-3636-8

The author would like to correct the Fig. 4 of the published article. The correct Fig. 4 is shown below:

Publisher's Note Springer Nature remains neutral with regard to jurisdictional claims in published maps and institutional affiliations.

The original article can be found online at https://doi.org/10.1007/ s00227-019-3636-8.

Yann Planque

yann.planque@univ-lr.fr

1 Centre d'Etudes Biologiques de Chizé, UMR 7372,

CNRS - La Rochelle Université, 5 allée de l'Océan,

17000 La Rochelle, France

2 Centre d'Etudes Biologiques de Chizé, UMR 7372, CNRS

- La Rochelle Université, 405 route de La Canauderie,

79360 Villiers-en-Bois, France 

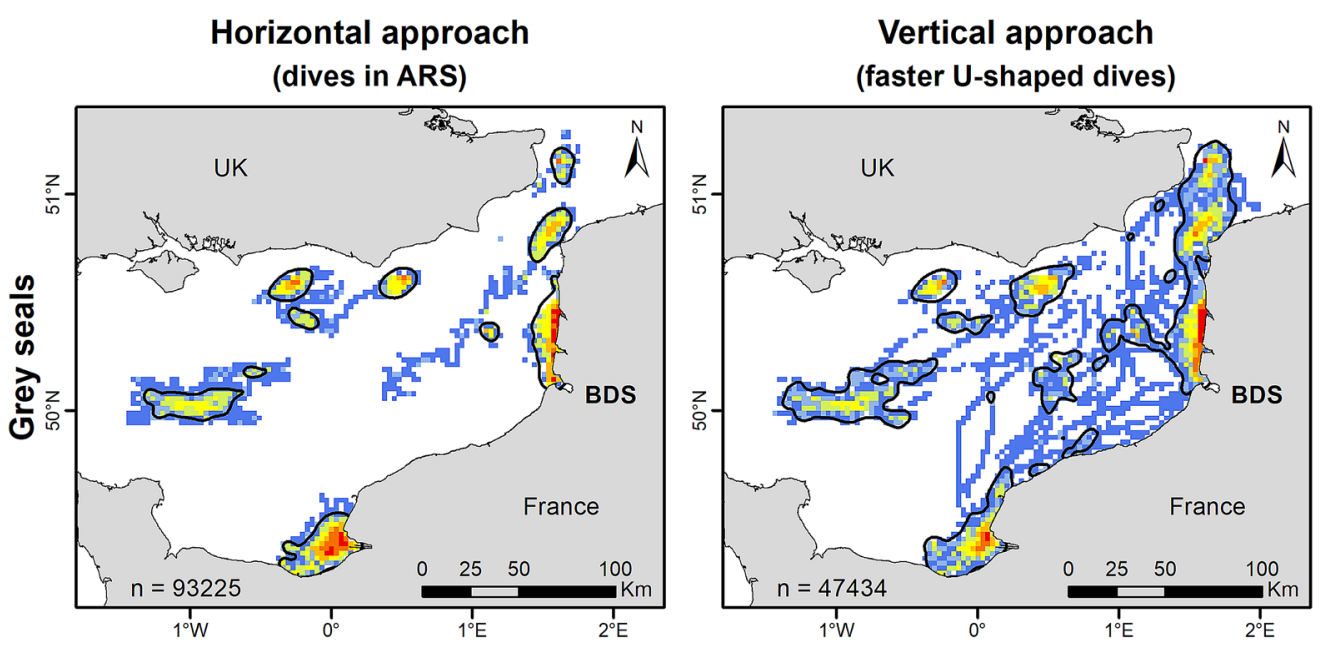

\section{Proportion of dives} $0 \%$

$$
\begin{aligned}
& \text { ]0\% }-0.025 \%] \\
& ] 0.025 \%-0.05 \%]
\end{aligned}
$$$$
] 0.05 \%-0.1 \%]
$$

] $0.1 \%-0.25 \%]$

] $0.25 \%-0.5 \%]$

] $0.5 \%-1 \%]$

$>1 \%$
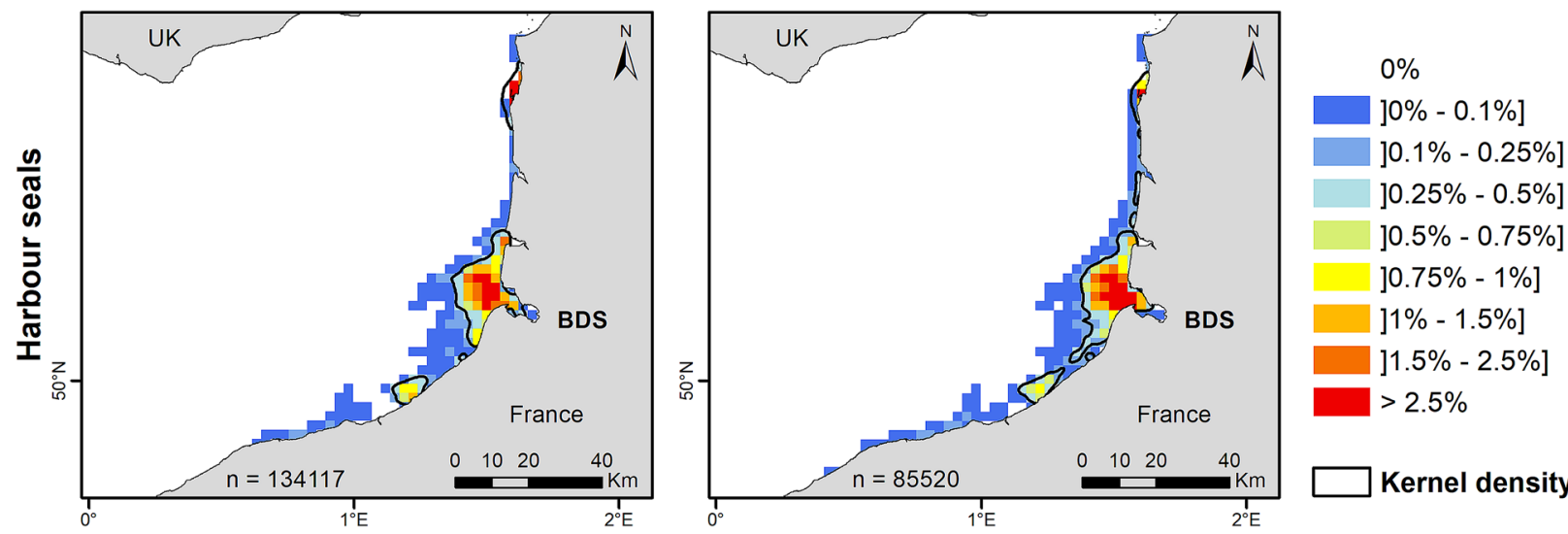

Kernel density (90\%)

Fig. 4 Grey and harbour seal foraging areas determined using the horizontal (left) and vertical (right) approaches. The foraging areas are represented on grids of $2.5 \times 2.5 \mathrm{~km}$ cells and characterized by the spatial density of dives in ARS selected from the hori- zontal approach and faster U-shaped dives selected from the vertical approach. Cores to extended foraging areas are represented by $90 \%$ kernel densities of foraging locations (black lines). BDS Baie de Somme, the capture site 